UDC 323:355.12(470.61)

Submitted: 11.02 .2019

LBC 66.3(2Poc-4Poc), 4

Accepted: 13.06.2019

\title{
MILITARY SERVICE OF THE COSSACKS IN THE SECURITY SYSTEM OF THE SOUTH OF RUSSIA (ON THE EXAMPLE OF ROSTOV REGION) ${ }^{1}$
}

\author{
Anton V. Bredikhin \\ Center of Security Studies of the Russian Academy of Sciences, Moscow, Russian Federation
}

\begin{abstract}
Introduction. Modern Russian Cossacks, having undergone the process of revival and institutionalization, are now incorporated into the system of state and other services of the Russian Federation. Given the pre-revolutionary status of the Cossacks as a military class of the Russian Empire, Ministry of Defense of the Russian Federation, beginning from the 1990s, has a particular interest in attracting the descendants of the Cossacks and members of Cossack societies to military service. Methods. Through the institutional analysis, the study assesses the role of the Cossacks in military service and security in the South of Russia. Analysis. In order to incorporate the Cossacks into the system of military service in the Russian Federation, a number of normative legal acts have been adopted that allow the Cossacks to serve in Cossack units with traditional Cossack names, to use Cossack insignia on military uniforms. As part of the implementation of the Strategy of the state policy of the Russian Federation in relation to the Russian Cossacks until 2020, regional plans for its implementation, Cossack societies are actively involved in the preparation of pre-conscription youth, interact with military commissariats. Recently, pilot projects have been launched to create specialized Cossack territorial defense companies. At a high level, the participation of the Cossacks in ensuring public order during important international events has been evaluated: the XXII Winter Olympic Games in Sochi, the World Cup 2018. Results. The need to expand the participation of the Cossacks in the military service of the Russian Federation by increasing the number of territorial defense companies, opening Cossack cadet corps, forming the role of the Cossacks as a guarantor of stabilization of interethnic relations of the South of Russia.

Key words: security, military service, military unit, Cossacks, Ministry of Defense of the Russian Federation, territorial defense company, South of Russia.

Citation. Bredikhin A.V. Military Service of the Cossacks in the Security System of the South of Russia (On the Example of Rostov Region). Vestnik Volgogradskogo gosudarstvennogo universiteta. Seriya 4. Istoriya. Regionovedenie. Mezhdunarodnye otnosheniya [Science Journal of Volgograd State University. History. Area Studies. International Relations], 2020, vol. 25, no. 5, pp. 234-243. (in Russian). DOI: https://doi.org/10.15688/ jvolsu4.2020.5.18
\end{abstract}

УДК 323:355.12(470.61)

ББК 66.3(2Poc-4Poc), 4

Дата поступления статьи: 11.02.2019

Дата принятия статьи: 13.06.2019

\section{ВОЕННАЯ СЛУЖБА КАЗАКОВ В СИСТЕМЕ БЕЗОПАСНОСТИ ЮГА РОССИИ (НА ПРИМЕРЕ РОСТОВСКОЙ ОБЛАСТИ) ${ }^{1}$}

\author{
Антон Викторович Бредихин \\ Центр исследования проблем безопасности РАН, г. Москва, Российская Федерация
}

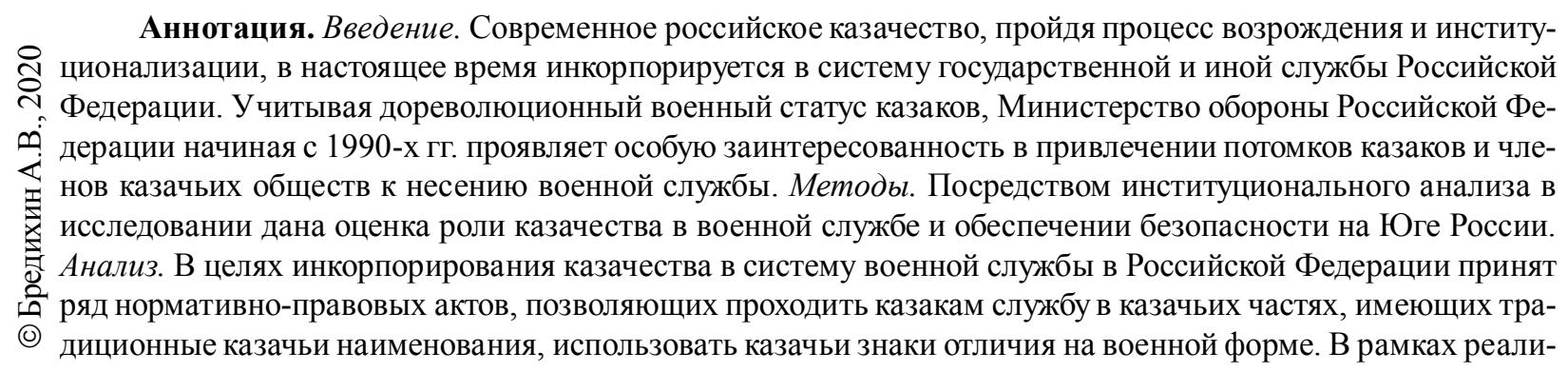


зации Стратегии государственной политики Российской Федерации в отношении российского казачества до 2020 г., региональных планов ее реализации казачьи общества активно участвуют в подготовке допризывной молодежи, взаимодействуют с военными комиссариатами. В последнее время запускаются пилотные проекты по созданию специализированных казачьих рот территориальной обороны. На высоком уровне дана оценка участия казаков в обеспечении общественного порядка в ходе значимых международных мероприятий: XXII Зимних Олимпийских игр в Сочи, чемпионата мира по футболу - 2018. Результатыл. Определена необходимость расширения участия казаков в военной службе Российской Федерации посредством увеличения числа рот территориальной обороны, открытия казачьих кадетских корпусов, формирования роли казачества как гаранта стабилизации межнациональных отношений Юга России.

Ключевые слова: безопасность, военная служба, воинская часть, казаки, Министерство обороны Российской Федерации, рота территориальной обороны, Юг России.

Цитирование. Бредихин А. В. Военная служба казаков в системе безопасности Юга России (на примере Ростовской области) // Вестник Волгоградского государственного университета. Серия 4, История. Регионоведение. Международные отношения. - 2020 - T. 25, № 5. - С. 234-243. - DOI: https://doi.org/10.15688/ jvolsu4.2020.5.18

Введение. «Граница породила казачество, а казаки создали Россию», - писал Лев Толстой. Донские, кубанские, терские, астраханские, яицкие и многие другие казаки выступали «живым щитом» империи, казачьи поселения находились вдоль ее границ, а в случае военных кампаний именно казаки составляли передовой авангард русской армии.

Дореволюционный статус казачества как военного сословия Российской империи в настоящее время приобретает актуальность и реализуется на практике. De facto период возрождения, начавшийся в 1980-е гг., завершен, и сейчас наступила важная стадия развития института казачества в системе органов государственной власти. Согласимся с профессором А.И. Агафоновым [1] в том, что казачество выступало в дореволюционной России частью государственного механизма по решению вопросов колонизации, военной службы, социально-политического развития общества. Данную функцию казаки возвращают себе и сейчас.

Современный Юг России, представленный в рамках Южного и Северо-Кавказского федеральных округов, претерпел ряд трансформационных процессов, межнациональных конфронтаций и военных конфликтов. Вместе с тем в условиях санкционного противостояния России и стран Запада усиливается роль дестабилизирующих факторов в регионе. В данной ситуации казачество сталкивается с рядом социально-политических кризисов и обладает значительным потенциалом для их преодоления.

В рамках данного исследования нами ставится цель рассмотрения сформировавше- гося статуса казачества в системе военной службы Российской Федерации и отражения данного процесса в системе безопасности, вызовов и угроз Юга России.

В исследовании предполагается рассмотреть следующие задачи:

- определить уровень современной инкорпорированности казачества в систему военной службы Российской Федерации;

- выявить основные формы реализации участия казачьих обществ в обеспечении деятельности Вооруженных Сил Российской Федерации;

- дать оценку перспективам деятельности казачьих обществ по предупреждению вызовов и угроз.

Методы и материалы. В рамках исследования используется институциональная методология, позволяющая определить роль казачества в укреплении национальной безопасности в регионе. В современной отечественной историографии аспект военной службы казаков рассматривается большей частью в дореволюционный период, периоды Гражданской и Великой Отечественной войны. Вопросы государственной службы российского казачества рассматриваются в статьях и диссертациях А.Н. Ворошилова [4], А.С. Кириченко [11], Г.О. Мациевского [13], Т.В. Седых [21], Д.Н. Соловьева [22] и других. Фактор добровольчества казаков в военно-политических конфликтах на постсоветском пространстве представлен в статьях С.О. Долгих [6], М.А. Махалкиной [12]. В данных работах рассматривается процесс принятия нормативно-правовых актов Российской Федера- 
ции по определению статуса казачьих обществ, формам взаимодействия с органами исполнительной власти, охраны границы, объектов природного и культурного значения. Значимой выступает практическая деятельность казачьих обществ и казаков с опытом участия в боевых действиях.

В то же время отсутствует либо недостаточно раскрыта проблема современного состояния военной службы российского казачества с учетом текущих угроз безопасности на Юге России.

Анализ. В период возрождения казачества широкий резонанс в общественном сознании имела идея того, что казаки представляются «ряжеными», одевающими незаконную форму и награды. Имидж казачества был значительно дискредитирован ввиду дезорганизации казачьих сообществ и декорпорации с системой государственного управления. Статус военного сословия, который имели казаки в дореволюционной России, не был регламентирован указом от 15.06.1992 № 632 «О мерах по реализации Закона Российской Федерации "О реабилитации репрессированных народов" в отношении казачества» [24], восстанавливающем историческую справедливость и осуждающем государственную политику репрессий.

Однако дальнейшее принятие нормативно-правовых актов в отношении российского казачества, создание ответственных органов исполнительной власти, участие казаков в ряде конфликтов на постсоветском пространстве в качестве добровольцев послужили основой для развития военной службы как одного из принципиально важных институтов жизни современных казачьих обществ.

Нормативно-правовые акты в отношении российского казачества. Активный процесс возрождения, самоорганизации казаков вызвал соответствующий интерес со стороны органов государственной власти. 15 марта 1993 г. Президентом Российской Федерации Б.Н. Ельциным был подписан Указ № 341 «О реформировании военных структур, пограничных и внутренних войск на территории Северо-Кавказского региона Российской Федерации и государственной поддержке казачества» [23]. В нем впервые вводилось прохождение казаками военной служ- бы в казачьих соединениях и частях Вооруженных Сил Российской Федерации, пограничных войск Министерства безопасности Российской Федерации, специальных казачьих моторизованных воинских частях и частях оперативного назначения внутренних войск Министерства внутренних дел Российской Федерации в соответствии с Законом Российской Федерации «О воинской обязанности и военной службе» и общевоинскими уставами Вооруженных Сил Российской Федерации. Минобороны России создавало первый перечень воинских частей для прохождения службы казаков с приданием им традиционных казачьих наименований. В Указе ставился вопрос утверждения казачьих воинских званий, а формат службы казаков в воинских частях определялся при сборе предложений от представителей казачьих организаций. В 2005 г. Указ утратил свою силу, хотя так до конца и не был реализован.

Основным нормативно-правовым документом, регламентирующим военную службу и деятельность по охране общественного порядка для членов казачьих обществ, сегодня выступает Федеральный закон № 154-Ф3 «О государственной службе российского казачества» [25]. В нем определено то, что для прохождения военной службы казаки направляются в соединения и воинские части Вооруженных Сил Российской Федерации, которым присвоены традиционные казачьи наименования, войска национальной гвардии Российской Федерации и пограничные части. Таковыми являются: 4-я гвардейская танковая Кантемировская ордена Ленина Краснознаменная дивизия имени Ю.В. Андропова в/ч 19612 (г. Наро-Фоминск, Московская область), 752-й мотострелковый полк в/ч 34670 (г. Валуйки, Белгородская область), 20-я отдельная гвардейская мотострелковая ПрикарпатскоБерлинская Краснознаменная ордена Суворова бригада в/ч 22220 (г. Волгоград), 108-й гвардейский десантно-штурмовой Кубанский казачий ордена Красной Звезды полк в/ч 42091 (г. Новороссийск, Краснодарский край), 33-я отдельная мотострелковая бригада в/ч 22179 (г. Майкоп, Республика Адыгея), 7-я гвардейская десантно-штурмовая Краснознаменная, орденов Суворова и Кутузова дивизия (горная) в/ч 61756 (г. Ставрополь), 205-я отдель- 
ная мотострелковая казачья бригада в/ч 74814 (г. Буденновск, Ставропольский край) и др. [18]. Казаки оказывают содействие государственным органам в организации и ведении воинского учета членов казачьих обществ, организуют военно-патриотическое воспитание призывников, их подготовку к военной службе и вневойсковую подготовку членов казачьих обществ во время их пребывания в запасе, принимают участие в обеспечении общественного порядка. «Казаки генетически предрасположены к армии и служат с усердием, они нужны на Кавказе, также могут служить на границе на Дальнем Востоке, ими лучше формировать легкие бригады», - полагает председатель общественного совета при Минобороны России Игорь Коротченко [5].

Внесены изменения в военную нормативно-правовую базу, позволяющую сохранить принадлежность к казачьему обществу при несении казаками военной службы. В соответствии с п. 89.1 «Правил ношения военной формы одежды, знаков различия, ведомственных знаков отличия и иных геральдических знаков в Вооруженных Силах Российской Федерации», членам войсковых казачьих обществ, внесенных в государственный реестр казачьих обществ Российской Федерации, во время прохождения ими военной службы в рядах Вооруженных Сил разрешается ношение на военной форме одежды нарукавных и нагрудных знаков различия по принадлежности к войсковому казачьему обществу [19].

Региональный опыт поддержки деятельности казачьих обществ. В субъектах Южного федерального округа реализуется ряд региональных программ, направленных на развитие военной службы в среде казачества. Например, в Ростовской области это государственная программа «Поддержка казачьих обществ Ростовской области» от 25.09.2013 № 601, предусматривающая финансирование казачества в 2019 г. на сумму 812912,3 тыс. руб., в 2020 г. - на сумму 805 487,5 тыс. рублей. К результатам данной программы отнесено и повышение обороноспособности государства посредством качественного укомплектования Вооруженных Сил Российской Федерации членами казачьих обществ, в том числе военно-обученными граж- данами, в период мобилизации и для разрешения кризисных ситуаций.

Вовлечение казаков в военную службу позволило создать в 2016 г. при содействии Министерства обороны Российской Федерации и войскового казачьего общества «Всевеликое войско Донское» роту территориальной обороны из казаков Донецкого, Новочеркасского, Первого Донского и Черкасского округов. Казаки, служащие в роте, принимали участие в учениях «Кавказ-2016», «Запад-2017», «Восток-2018». В рамках Кубанского войскового казачьего общества создана 1-я Таманская казачья дивизия, регулярно проводящая военно-полевые сборы и, по заявлениям руководства, готовая к участию в миротворческих операциях [9]. Там же в Краснодарском крае создана первая в России казачья рота Росгвардии [15].

Донские и кубанские казаки обеспечили безопасность в рамках проведения XXII Зимних Олимпийских игр в Сочи в 2014 г., Чемпионата мира по футболу в Ростове-на-Дону, Волгограде, Сочи в 2018 году. Первый заместитель Губернатора Ростовской области, атаман ВКО «Всевеликое войско Донское» В.Г. Гончаров так определил роль казаков в рамках данных мероприятий: «Донские казаки не просто покорили зарубежных фанатов своим гостеприимством, добродушием, традиционными обычаями и культурой, но и несли службу по обеспечению безопасности и профилактике правонарушений в период мундиаля. Службу казаков высоко оценили власти регионов, силовые структуры и, главное, наши гости, а также жители городов и станиц» [2]. С ним солидарен заместитель губернатора Краснодарского края, атаман Кубанского войскового казачьего общества Н.А. Долуда: «Живой интерес и доброжелателей, искренне радеющих за судьбу казачества, и тех, кто не хочет видеть в нем силу и мощный ресурс для укрепления безопасности России, - подтверждает факт того, что кубанское казачество находится сегодня на передовых позициях, в самой гуще исторических событий, определяющих судьбу страны, ее суверенность и стабильность. К событиям такого масштаба можно отнести Крымскую весну, юбилейный Парад Победы на Красной площади Москвы, охрана общественного по- 
рядка казаками во время проведения Олимпийских и Паралимпийских игр в Сочи в 2014 г., международного этапа гонок “Формула-1", Кубка Конфедерации по футболу в 2017» [14].

Военное направление деятельности казачьих обществ. Российское казачество выступает активным участником уреглуирования социально- и военно-политических конфликтов на постсоциалистическом пространстве. Посредством института добровольчества казаки принимали участие в межнациональных конфликтах в Абхазии, Боснии и Герцеговине, Приднестровье, Южной Oceтии - Алании и других. В последние годы это участие в «пятидневной войне» с Грузией, событиях «Русской весны» и возвращении Крымского полуострова в состав Российской Федерации, конфликте в Донбассе, противостоянии Исламскому Государству в Сирии ${ }^{2}$. В рамках так называемых «частных военных кампаний» казаки проявили себя в Ливии, Центральноафриканской республике, Венесуэле и ряде других стран. При этом основными участниками выступили представители общественных, а не реестровых казачьих обществ, как, например, Казачья национальная гвардия атамана МСОО «Всевеликое войско Донское» Н.И. Козицына, фактически создавшая на территории Луганщины казачью республику.

Деятельность казачьих обществ по предотвращению вызовов в южнороссийских регионах в 2019-2020 гг. представлена в Плане мероприятий по реализации в 2017-2020 гг. Стратегии развития государственной политики Российской Федерации в отношении российского казачества до 2020 г., утвержденного распоряжением Правительства Российской Федерации от 17 февраля 2017 г. № 285-р (далее - План) [20].

В соответствии с п. 6 Плана предусмотрено привлечение российского казачества к участию в защите государственной границы Российской Федерации. Данный пункт имеет свою реализацию на постоянной основе и пример создания роты территориальной обороны, а согласно позиции руководства войскового казачьего общества «Всевеликое войско Донское» будет создана еще одна [10], выступает тому подтверждением. Вместе с тем широко распространенной выступает практика охраны государственной границы казачьими обществами на основании трехстороннего соглашения между руководством региона, ФСБ России и казачьим обществом, как, например, это имело место в Республике Северная Осетия - Алания [3] и границе с Республикой Абхазией. В период активной фазы военного конфликта в Донбассе в 2014 г. донские казаки были направлены на усиление пограничной службы на ряде участков российско-украинской границы [7]. Существует мнение о более активном привлечении казаков к охране границ с Китаем, Японией, Грузией, Польшей, Литвой [8].

В соответствии с п. 9 Плана на базе центров военно-патриотического воспитания Общероссийской общественно-государственной организации «Добровольное общество содействия армии, авиации и флоту России» осуществляется подготовка к службе в рядах Вооруженных Сил Российской Федерации лиц из числа членов казачьих обществ и общественных объединений казаков. Соглашения о сотрудничестве с ДОСААФ заключил ряд войсковых казачьих обществ, а также Общероссийская общественная организация по развитию казачества «Союз казаков-воинов России и Зарубежья», что позволяет формировать полную систему допризывной подготовки казачьей молодежи.

Пункты 15 и 16 Плана определяют прохождение членами казачьих обществ военной службы в 90-м отдельном специальном поисковом батальоне Минобороны России, войсках Росгвардии.

Региональные планы мероприятий по реализации Стратегии развития государственной политики Российской Федерации в отношении российского казачества до 2020 г. предусматривают более конкретные меры вовлечения казаков в военную службу, подкрепленные мероприятиями. В Ростовской области в рамках соглашений оказания содействия федеральному государственному казенному учреждению «Пограничное управление Федеральной службы безопасности Российской Федерации по Ростовской области» дружинниками ВКО «Всевеликое войско Донское»осуществляются функции по защите государственной границы Российской Федерации в порядке, установленном уставом ВКО «Всевеликое войско Донское» [17]. 
Государственной программой Ростовской области «Поддержка казачьих обществ Ростовской области» предусмотрено повышение обороноспособности государства посредством качественного укомплектования Вооруженных Сил Российской Федерации членами казачьих обществ, в том числе военнообученными гражданами, в период мобилизации и для разрешения кризисных ситуаций [16]. По аналогии реализуются региональные программы в Краснодарском и Ставропольском краях, Волгоградской и Астраханской областях. Дополнением к военной службе казаков выступает охрана общественного порядка и развитие системы казачьего кадетского образования.

Результаты. На основании изложенного переходим к выводам.

Во-первых, казачество зарекомендовало себя с позиции перспективного резерва Вооруженных Сил Российской Федерации, что возможно благодаря действующей нормативно-правовой базе, федеральной и региональных стратегий и программ.

Во-вторых, казачество активно участвует в комплектовании казачьих частей Вооруженных Сил Российской Федерации, создает роты территориальной обороны, проявляет себя в качестве добровольцев в военно-политических конфликтах не только на постсоветском пространстве, но и в других регионах планеты, где присутствуют российские геополитические интересы.

В-третьих, потенциал военной службы казачества до конца не раскрыт, требуется увеличение числа казачьих территориальных рот, признание казачьих званий в системе военных званий, переход казаков к стабилизирующей роли в системе межнациональных отношений Юга России в качестве одного из столпов формирующейся российской нации.

\section{ПРИМЕЧАНИЯ}

${ }^{1}$ Статья подготовлена при финансовой поддержке Российского научного фонда (проект № 17-68-00001 «Влияние институциональной нестабильности сопредельных стран на деятельность экстремистских организаций Юга России»). ФГБУН Центр исследования проблем безопасности Российской академии наук.
This article was prepared with the financial support of the Russian Science Foundation (project no. 17-68-00001 "The impact of institutional instability in neighboring countries on the activities of extremist organizations in the South of Russia"). Center for Security Research of the Russian Academy of Sciences.

2 Запрещенная в Российской Федерации террористическая организация.

\section{СПИСОК ЛИТЕРАТУРЫ}

1. Агафонов, А. И. От Земли Донского войска к Области Войска Донского (середина XIX - начало XX века) / А. И. Агафонов // Известия высших учебных заведений. Северо-Кавказский регион. Серия: Общественные науки. - 2017. - № 3 (195). C. 28-37.

2. Атаман войскового казачьего общества «Всевеликое войско Донское» Виктор Гончаров поздравил казаков с Новым годом и Рождеством // Российское казачество. - Электрон. текстовые дан. - Режим доступа: http://ruskazaki.ru/news/ kazachestvo/ataman_voyskovogo_kazachego_ obshchestva_vsevelikoe_voysko_donskoe_viktor_ goncharov_pozdravil_kazakov (дата обращения: 10.02.2019). - Загл. с экрана.

3. В Северной Осетии казаки приступают к охране Российской границы // Казачий информационно-аналитический центр. - Электрон. текстовые дан. - Режим доступа: http://kazak-center.ru/ news/1/2010-01-24-309 (дата обращения: 07.02.2019).Загл. с экрана.

4. Ворошилов, А. Н. Современные организационно-правовые формы казачьего самоуправления на Дону : автореф. дис. ... канд. юрид. наук / Ворошилов Анастасий Николаевич. - Ростов н/Д, 2007. -29 с.

5. Генштаб увеличит число казачьих частей в армии // Известия. - Электрон. текстовые дан. Режим доступа: https://iz.ru/news/532117 (дата обращения: 31.01.2019). - Загл. с экрана.

6. Долгих, С. О. Казачество в истории локальных конфликтах конца XX в. / С. О. Долгих // Вестник Томского государственного университета. История. - 2018. - № 54. - С. 33-37.

7. Донские казаки приступили к охране государственной границы в Ростовской области // Синодальный комитет по взаимодействию с казачеством. - Электрон. текстовые дан. - Режим доступа: http://www.skvk.org/18496 (дата обращения: 07.02.2019). - Загл. с экрана.

8. Казакам доверят охранять границы России с Польшей, Литвой, Китаем и Японией // RT. - Электрон. текстовые дан. - Режим доступа: https:// russian.rt.com/article/326739-kazakam-doveryat- 
ohranyat-granicy-rossii-s-polshei (дата обращения: 07.02.2019). - Загл. с экрана.

9. Казачья дивизия готовится к миротворческим операциям // Военное обозрение. - Электрон. текстовые дан. - Режим доступа: https://topwar.ru/ 147077-kazachja-divizija-gotovitsja-k-mirotvorcheskimoperacijam.html (дата обращения: 10.02.2019). - Загл. с экрана.

10. Казачья рота приступила к обучению // Войсковое казачье общество «Всевеликое войско Донское». - Электрон. текстовые дан. - Режим доступа: http://www.don-kazak.ru/news/kazachya-rota-pristupilak-obucheniyu/?sphrase_id=10336 (дата обращения: 07.02.2019). - Загл. с экрана.

11. Кириченко, А. С. Политико-административное регулирование и управление казачьими обществами Юга России: на материалах Ростовской области : дис. ... канд. полит. наук / Кириченко Алексей Сергеевич. - Ростов н/Д, 2005. - 175 с.

12. Махалкина, М. А. Участие казаков-добровольцев в локальных конфликтах на пространстве бывшего СССР / М. А. Махалкина // Непризнанные государства: методологические, политические и правовые аспекты : сб. материалов Всерос. науч. конф. - Самара : Самарская гуманитарная академия, 2016. - С. 71-75.

13. Мациевский, Г. О. Государство и казачество: поиск путей возрождения / Г. О. Мациевский // Вестник Томского государственного университета. - 2017. - № 424. - С. 97-104.

14. Н.А. Долуда: «Казакам можно доверять защиту рубежей России!» // Кубанское казачье войско. - Электрон. текстовые дан. - Режим доступа: http://slavakubani.ru/articles/n-a-doluda-kazakammozhno-doveryat-zashchitu-rubezhey-rossii (дата обращения: 10.02.2019). - Загл. с экрана.

15. Первая в России казачья рота Росгвардии укомплектована в Краснодарском крае // Кубанские новости. - Электрон. текстовые дан. - Режим доступа: https://kubnews.ru/obshchestvo/2018/02/20/pervaya-vrossii-kazachya-rota-rosgvardii-ukomplektovana-vkrasnodarskom-krae (дата обращения: 10.02.2019). - Загл. с экрана.

16. Правительство Ростовской области. Постановление от 25.09.2013 № 601 «Об утверждении государственной программы Ростовской области "Поддержка казачьих обществ Ростовской области"». - Электрон. текстовые дан. - Режим доступа: http://www.donland.ru/documents/Ob-utverzhdeniigosudarstvennojj-programmy-Rostovskojj-oblastiPodderzhka-kazachikh-obshhestv-Rostovskojjoblasti?pageid $=128483 \&$ mid $=134977 \&$ itemId $=22413$ (дата обращения: 09.02.2019). - Загл. с экрана.

17. Правительство Ростовской области. Распоряжение от 23.12.2016 № 672 «Об угверждении плана мероприятий по реализации в 2017-2020 годах
Стратегии развития государственной политики Российской Федерации в отношении российского казачества до 2020 года в Ростовской области». - Электрон. текстовые дан. - Режим доступа: http:// www.donland.ru/documents/Ob-utverzhdenii-planameropriyatijj-po-realizacii-v-2017---2020-godakhStrategii-razvitiya-gosudarstvennojj-politikiRossijjskojj-Federacii?pageid $=128483 \& \mathrm{mid}=$ 134977\&itemId=24908 (дата обращения: 09.02.2019). Загл. с экрана.

18. Призыв и военная служба в ВС РФ // Центральное казачье войско. - Электрон. текстовые дан. Режим доступа: http://www.vko-ckv.ru/kazachyasluzhba/prizyv-i-voennaya-sluzhba (дата обращения: 31.01.2019). - Загл. с экрана.

19. Приказ Министра обороны Российской Федерации от 26.11.2018 № 677 «О внесении изменений в приказ Министра обороны Российской Федерации от 22 июня 2015 г. № 300 “Об утверждении Правил ношения военной формы одежды, знаков различия, ведомственных знаков отличия и иных геральдических знаков в Вооруженных Силах Российской Федерации и Порядка смешения предметов существующей и новой военной формы одежды в Вооруженных Силах Российской Федерации"». - Доступ из информ.-правового портала «Гарант.ру».

20. Распоряжение Правительства РФ от 17.02.2017 № 285-р «Об утверждении плана мероприятий по реализации в 2017-2020 гг. Стратегии развития государственной политики РФ в отношении российского казачества до 2020 г.». - Доступ из информ.-правового портала «Гарант.ру».

21. Седых, Т. В. Политико-правовые основы государственной службы российского казачества в начале XXI в. / Т. В. Седых // Известия высших учебных заведений. Поволжский регион. Общественные науки. - 2010. - № 2 (14). - С. 31-37.

22. Соловьев, Д. Н. Национальные интересы и казачества в системе безопасности / Д. Н. Соловьев // Национальные интересы: приоритеты и безопасность. - 2011. - № 30 (123). - С. 58-60.

23. Указ Президента РФ от 15.03.1993 № 341 «О реформировании военных структур, пограничных и внутренних войск на территории Северо-Кавказского региона Российской Федерации и государственной поддержке казачества». - Доступ из информ.-правового портала «Гарант.ру».

24. Указ Президента РФ от 15.06.1992 № 632 «О мерах по реализации Закона Российской Федерации “О реабилитации репрессированных народов" в отношении казачества». - Доступ из информ.-правового портала «Гарант.ру».

25. Федеральный закон от 05.12.2005 № 154-Ф3 «О государственной службе российского казачества». - Доступ из информ.-правового портала «Гарант.ру». 


\section{REFERENCES}

1. Agafonov A.I. Ot Zemli Donskogo voyska $\mathrm{k}$ Oblasti Voyska Donskogo (seredina XIX - nachalo XX veka) [From the Land of the Don Army to the Don Army Region (the Middle of $19^{\text {th }}-$ Beginning of $20^{\text {th }}$ Century)]. Izvestiya vysshykh uchebnykh zavedeniy. Severo-Kavkazskiy region. Seriya: Obshchestvennye nauki [News of Higher Educational Institutions. North Caucasus Region. Series: Social Sciences], 2017, no. 3 (195), pp. 28-37.

2. Ataman voyskovogo kazachyego obshchestva «Vsevelikoe voysko Donskoe» Viktor Goncharov pozdravil kazakov s Novym godom i Rozhdestvom [Ataman of the Cossack Army Society “All-Great Army of the Don” Victor Goncharov Congratulated the Cossacks on New Year and Christmas]. Rossiyskoe kazachestvo. URL: http:// ruskazaki.ru/news/kazachestvo/ataman_voyskovogo_ kazachego_obshchestva_vsevelikoe_voysko_ donskoe_viktor_goncharov_pozdravil_kazakov (accessed 10 February 2019).

3. V Severnoy Osetii kazaki pristupayut $\mathrm{k}$ okhrane Rossiyskoy granitsy [In North Ossetia Cossacks Start Protection of the Russian Border]. Kazachiy informatsionno-analiticheskiy tsentr. URL: http://kazak-center.ru/news/1/2010-01-24-309 (accessed 7 February 2019).

4. Voroshilov A.N. Sovremennye organizatsionnopravovye formy kazachyego samoupravleniya na Donu: avtoref. dis. kand. yurid. nauk [Modern Organizational and Legal Forms of Cossack SelfGovernment on the Don. Cand. jurid. sci. abs. diss.]. Rostov-on-Don, 2007.29 p.

5. Genshtab uvelichit chislo kazachyikh chastey v armii [The General Staff Will Increase the Number of Cossack Units in the Army]. Izvestiya. URL: https:// iz.ru/news/532117 (accessed 31 January 2019).

6. Dolgih S.O. Kazachestvo v istorii lokalnykh konfliktakh kontsa XX v. [Cossacks in the History of Local Conflicts of the Late $20^{\text {th }}$ Century]. Vestnik Tomskogo gosudarstvennogo universiteta. Istoriya [Bulletin of Tomsk State University. History], 2018, no. 54, pp. 33-37.

7. Donskie kazaki pristupili k okhrane gosudarstvennoy granitsy v Rostovskoy oblasti [Don Cossacks Started Protection of the State Border in Rostov Region]. Sinodalnyy komitet po vzaimodeystviyu s kazachestvom [Synodal Committee on Interaction with the Cossacks]. URL: http://www. skvk.org/18496 (accessed 7 February 2019).

8. Kazakam doveryat okhranyat granitsy Rossii s Polshey, Litvoy, Kitaem i Yaponiey [Cossacks Will Be Entrusted to Guard the Borders of Russia with Poland, Lithuania, China and Japan]. RT [RT]. URL: https:// russian.rt.com/article/326739-kazakam-doveryat-ohranyatgranicy-rossii-s-polshei (accessed 7 February 2019).
9. Kazachya diviziya gotovitsya $\mathrm{k}$ mirotvorcheskim operatsiyam [Cossack Division Preparing for Peacekeeping Operations]. Voennoe obozrenie. URL: https://topwar.ru/147077-kazachjadivizija-gotovitsja-k-mirotvorcheskim-operacijam.html (accessed 10 February 2019).

10. Kazachya rota pristupila $\mathrm{k}$ obucheniyu [Cossack Company Began Training]. Voyskovoe kazachye obshchestvo "Vsevelikoe voysko Donskoe». URL: http://www.don-kazak.ru/news/kazachya-rotapristupila-k-obucheniyu/?sphrase_id=10336 (accessed 7 February 2019).

11. Kirichenko A.S. Politiko-administrativnoe regulirovanie i upravlenie kazachyimi obshchestvami Yuga Rossii: na materialakh Rostovskoy oblasti: dis. ... kand. polit. nauk [Political and Administrative Regulation and Management of Cossack Societies in the South of Russia: On the Materials of the Rostov Region. Cand. polit. sci. diss.]. Rostov-on-Don, 2005. 175 p.

12. Mahalkina M.A. Uchastie kazakovdobrovoltsev v lokalnykh konfliktakh na prostranstve byvshego SSSR [The Involvement of Cossack Volunteers in Local Conflicts in the Former USSR]. Nepriznannye gosudarstva: metodologicheskie, politicheskie i pravovye aspekty: sb. mat. Vseros. nauch. konf. [Unrecognized States: Methodological, Political, and Legal Aspects. Proceedings of the AllRussian Scientific Conference]. Samara, Samarskaya gumanitarnaya akademiya, 2016, pp. 71-75.

13. Macievskij G.O. Gosudarstvo i kazachestvo: poisk putey vozrozhdeniya [The State and the Cossacks: Search of Ways of Renewal]. Vestnik Tomskogo gosudarstvennogo universiteta [Bulletin of the Tomsk state University], 2017, no. 424, pp. 97-104.

14. N.A. Doluda: «Kazakam mozhno doveryat zashchitu rubezhey Rossii!» [N.A. Doluda: "Cossacks Can be Trusted with the Protection of Borders of Russia!"] Kubanskoe kazachye voysko. URL: http:// slavakubani.ru/articles/n-a-doluda-kazakam-mozhnodoveryat-zashchitu-rubezhey-rossii (accessed 10 February 2019).

15. Pervaya v Rossii kazachya rota Rosgvardii ukomplektovana v Krasnodarskom krae [The First Russian Cossack Company of Rosgvardiya Staffed in Krasnodar Krai]. Kubanskie novosti. URL: https:// kubnews.ru/obshchestvo/2018/02/20/pervaya-vrossii-kazachya-rota-rosgvardii-ukomplektovana-vkrasnodarskom-krae (accessed 10 February 2019).

16. Pravitelstvo Rostovskoy oblasti. Postanovlenie ot 25.09.2013 № 601 «Ob utverzhdenii gosudarstvennoy programmy Rostovskoy oblasti «Podderzhka kazachyikh obshchestv Rostovskoy oblasti» [Government of Rostov Region. Resolution № 601 of 25 September 2013. “About the Approval of the State Program of Rostov Region "Support of Cossack Societies of Rostov Region"]. URL: http:// 
www.donland.ru/documents/Ob-utverzhdeniigosudarstvennojj-programmy-Rostovskojj-oblastiPodderzhka-kazachikh-obshhestv-Rostovskojjoblasti?pageid=128483\&mid=134977\&itemId=22413 (accessed 9 February 2019).

17. Pravitelstvo Rostovskoy oblasti. Rasporyazhenie ot 23.12.2016 № 672 «Ob utverzhdenii plana meropriyatiy po realizatsii $v$ 2017-2020 godakh Strategii razvitiya gosudarstvennoy politiki Rossiyskoy Federatsii v otnoshenii rossiyskogo kazachestva do 2020 goda $v$ Rostovskoy oblasti» [Government of Rostov Region. Order No. 672 of 23 December 2016 “On Approval of the Action Plan for the Implementation in 2017-2020 of the Strategy for the Development of the State Policy of the Russian Federation with Regard to the Russian Cossacks Until 2020 in Rostov Region"]. URL: http:// www.donland.ru/documents/Ob-utverzhdenii-planameropriyatijj-po-realizacii-v-2017---2020-godakhStrategii-razvitiya-gosudarstvennojj-politikiRossijjskojj-Federacii-?pageid=128483\&mid= 134977\&itemId=24908 (accessed 9 February 2019).

18. Prizyv i voennaya sluzhba v VS RF [Conscription and Military Service in the Armed Forces]. Tsentralnoe kazachye voysko. URL: http:// www.vko-ckv.ru/kazachya-sluzhba/prizyv-i-voennayasluzhba (accessed 31 January 2019).

19. Prikaz Ministra oborony Rossiyskoy Federatsii ot 26.11.2018№ 677 «O vnesenii izmeneniy v prikaz Ministra oborony Rossiyskoy Federatsii ot 22 iyunya 2015 g. № 300 "Ob utverzhdenii pravil nosheniya voyennoy formy odezhdy, znakov razlichiya, vedomstvennykh znakov $v$ Vooruzhennykh Silakh Rossiyskoy Federatsii i Poryadka smesheniya predmetov sushchestvuyushchey i novoy voyennoy formy odezhdy $v$ Vooruzhennykh Silakh Rossiyskoy Federatsii" 》" [Order of the Minister of Defense of the Russian Federation No. 677 of 26 November 2018 “On Amendments to the Order of the Minister of Defense of the Russian Federation of June 22, 2015 No. 300 On Approval of the Rules for Wearing Military Uniforms, Insignia, Departmental Insignia and Other Heraldic Insignia in the Armed Forces of the Russian Federation and the Procedure for Mixing Items of the Existing and New Military Uniforms in the Armed Forces of the Russian Federation"]. Access from "Garant" informational and legal web portal.

20. Rasporyazhenie Pravitelstva RF ot 17.02.2017 № 285-r Ob utverzhdenii plana meropriyatiy po realizatsii v 2017-2020 gg. Strategii razvitiya gosudarstvennoy politiki $R F \quad v$ otnoshenii rossiyskogo kazachestva do $2020 \mathrm{~g}$. [Decree of the RF Government of 17 February 2017 No. 285-r Approving the Plan of Measures for Implementation in 2017-2020 of the Development Strategy of the State Policy of the Russian Federation Concerning the Russian Cossacks Until 2020]. Access from "Garant" informational and legal web portal.

21. Sedyh T.V. Politiko-pravovye osnovy gosudarstvennoy sluzhby rossiyskogo kazachestva v nachale XXI v. [Political and Legal Bases of Public Service of the Russian Cossacks in the Beginning of $21^{\text {st }}$ Century]. Izvestiya vysshikh uchebnykh zavedeniy. Povolzhskiy region. Obshchestvennye nauki [Proceedings of Higher Educational Institutions. Volga Region. Social Sciences], 2010, no. 2 (14), pp. 31-37.

22. Solovev D.N. Natsionalnye interesy i kazachestvo v sisteme bezopasnosti [National Interests and Cossacks in the Security System]. Natsionalnye interesy: prioritety $i$ bezopasnost [National Interests: Priorities and Security], 2011, no. 30 (123), pp. 58-60.

23. Ukaz Prezidenta RF ot 15.03.1993 № 341 «O reformirovanii voennykh struktur, pogranichnykh $i$ vnutrennikh voysk na territorii SeveroKavkazskogo regiona Rossiyskoy Federatsii $i$ gosudarstvennoy podderzhke kazachestva» [Decree of the President of the Russian Federation of 15 March 1993 No. 341 “About Reforming of Military Structures, Frontier and Interior Forces on the Territory of the North Caucasus Region of the Russian Federation and State Support of the Cossacks"]. Access from "Garant" informational and legal web portal.

24. Ukaz Prezidenta RF ot 15.06.1992 № 632 «O merakh po realizatsii Zakona Rossiyskoy Federatsii "O reabilitatsii repressirovannykh narodov" $v$ otnoshenii kazachestva» [Decree of the President of the Russian Federation of 15 June 1992 No. 632 "On Measures to Implement the Law of the Russian Federation On the Rehabilitation of Repressed Peoples in Relation to the Cossacks"]. Access from "Garant" informational and legal web portal.

25. Federalnyy zakon ot 05.12.2005 № 154-FZ «O gosudarstvennoy sluzhbe rossiyskogo kazachestva» [Federal Law No. 154-FZ of 5 November 2005 "On the State Service of the Russian Cossacks"]. Access from "Garant" informational and legal web portal. 


\section{Information About the Author}

Anton V. Bredikhin, Candidate of Sciences (History), Advisor to the Director, Center of Security Studies of the Russian Academy of Sciences, Garibaldi St, 21b, 117335 Moscow, Russian Federation, bredikhin90@yandex.ru,https://orcid.org/0000-0003-4097-3854

\section{Информация об авторе}

Антон Викторович Бредихин, кандидат исторических наук, советник директора, Центр исследования проблем безопасности РАН, ул. Гарибальди, 21б, 117335 г. Москва, Российская Федерация, bredikhin90@yandex.ru, https://orcid.org/0000-0003-4097-3854 